\title{
Blunt Instrument: The Inevitable Inaccuracy of an All-or-Nothing On-Sale Bar
}

\author{
Winslow B. Taub ${ }^{\dagger}$
}

For the last 170 years, United States patent law has barred inventors from obtaining patents on inventions that were on sale before the inventor filed the patent application, subject to some grace period. Courts have struggled to formulate a clear and fair standard for what conduct by an inventor places an invention "on sale." The current test, articulated by the Federal Circuit, requires only that the invention, when "ready for patenting," be the subject of a contractual offer for sale-one that would be binding upon acceptance. This test, though easier to administer than its predecessors, in many cases yields results that are completely arbitrary with respect to the goals of the patent system. This Comment explains that the arbitrariness stems not from the choice of standard, but from the structure of the bar as a binary, all-or-nothing rule. A sliding bar would better address the goals of the patent system. Finally, this Comment extrapolates from the on-sale bar to statutory bars in other legal contexts, explaining how a similar structural defect inheres in other all-or-nothing, time-triggered rules.

\section{INTRODUCTION}

Consider the following hypothetical inventors.

MicroChips, a small semiconductor company, contracts with a third party to manufacture 20,000 units of its new chip in anticipation of selling the chip to the public. Behemoth Inc., a competitor with its own fabrication facilities, manufactures and stockpiles the same number of its competing

Copyright $(2004$ California Law Review, Inc. Califomia Law Review, Inc. (CLR) is a Califomia nonprofit corporation. CLR and the authors are solely responsible for the content of their publications.

$\dagger \quad$ J.D., School of Law, University of Califomia, Berkeley (Boalt Hall), 2004. 1 am greatly obliged to Professors Peter Menell and Robert Cooter of Boalt Hall for their comments and suggestions. 1 am also grateful for the encouragement of Mark Rowland and Norm Beamer of Fish \& Neave, and of Ed Reines of Weil, Gotshal \& Manges. 
chip in-house. One year later, both companies file applications for patents on their chip designs.

Sam, an electrical engineer, builds an improved computer peripheral device in his garage and offers to sell it to his neighbor, who is not interested. At the same time, Sumo, Inc., a multinational computer hardware manufacturer, initiates a six-month advertising campaign for its new peripheral on television, on the Internet, and in print publications worldwide prior to distributing the peripheral for sale to the public. One year later, both Sam and Sumo file for patents on their peripherals.

Under current law, both MicroChips and Sam placed their inventions on sale more than a year before filing their patent applications and are barred from obtaining patents. ${ }^{1}$ Behemoth and Sumo, under current law, did not place their inventions on sale and may obtain the reward of a twenty-year right to exclude others from practicing their inventions. ${ }^{2}$ Current federal circuit case law considers only whether the invention was the subject of a contractual offer to sell in determining whether it was on sale too long before the filing date, raising an absolute bar to patentability. ${ }^{3}$ As this Comment will demonstrate, this all-or-nothing rule fails to adequately address the patent system's broad goal of encouraging invention and disclosure through the grant of a limited monopoly. ${ }^{4}$

Since the Patent Act of $1836,{ }^{5}$ any invention that has been on sale for more than a specified period of time before the filing date of the patent application may not be the subject of a patent. ${ }^{6}$ This is known as the "on-sale bar." Various courts have formulated different meanings for "on sale," but with several shared characteristics. ${ }^{7}$ Courts have not required a completed sale to trigger the bar; rather, an offer to sell the invention is sufficient. $^{8}$ Historically, some amount of aggressive marketing has also triggered the bar in most jurisdictions. ${ }^{9}$ The Federal Circuit and several of the regional circuits eventually settled on a complex "totality of the circumstances" test for determining what level of commercial activity

\footnotetext{
1. See infra Part I.F.

2. Id.

3. Group One, Ltd. v. Hallmark Cards, Inc., 254 F.3d 1041, 1048 (Fed. Cir. 2001).

4. See, e.g., Metallizing Eng'g Co. v. Kenyon Bearing \& Auto Parts Co., I53 F.2d 516, 520 (2d Cir. 1946).

5. Patent Act of I836, ch. 357, § 6, 5 Stat. I I7, I 19 (repealed I870).

6. See Pfaff v. Wells Elecs., Inc., 525 U.S. 55, 65 (1998) (describing the earliest patent statutes that included the on-sale bar).

7. See generally UMC Elecs. Co. v. United States, 816 F.2d 647, 65I-56 (Fed. Cir. 1987) (surveying the judicial evolution of the on-sale bar).

8. Wende v. Horine, 225 F. 501, 505 (7th Cir. 1915).

9. Barmag Barmer Maschinenfabrik AG v. Murata Machinery, Ltd., 73I F.2d 831, 839 (Fed. Cir. 1984); In re Theis, 610 F.2d 786, 792 (C.C.P.A. 1979); Red Cross Mfg. Corp. v. Toro Sales Co., 525 F.2d 1135, $1139-40$ (7th Cir. 1975); Amphenol Corp. v. Gen. Time Corp., 397 F.2d 431, 433 (7th Cir. 1968).
} 
served to raise the bar. ${ }^{10}$ Under this test, a court would consider the inventor's attempts to commercially exploit the invention and weigh those activities against the policies underlying the on-sale bar in order to decide whether to invalidate a patent under the on-sale bar."

The Supreme Court, in Pfaff $v$. Wells Electronics, Inc., abrogated the totality of the circumstances test in favor of the requirement that the invention be the subject of a "commercial offer for sale" in order to trigger the on-sale bar. ${ }^{12}$ The Federal Circuit has since interpreted this requirement narrowly by holding that only a contractual offer will suffice. ${ }^{13}$ The hypothetical scenarios above illustrate two of the strange results that are consequences of this rigid test.

First, as illustrated by MicroChips and Behemoth, courts have found the bar to apply even where the inventor is the buyer rather than the seller. ${ }^{14}$ An inventor who lacks manufacturing facilities and enters into a foundry arrangement with a manufacturer necessarily contracts to buy the finished product from the manufacturer. ${ }^{15}$ Thus, even before the inventor has offered a single product for sale to the public, the bar may be raised. Second, as illustrated by Sam and Sumo, an inventor's single, unprofitable (but contractual) offer to sell the invention will raise the bar, while an inventor's aggressive marketing of an invention will not trigger the bar, even if the marketing is of great commercial advantage. ${ }^{16}$

These strange distinctions exist because a contract-based test does not capture the harms that flow from granting a patent on an invention that is already in commerce. A contractual offer must be definite and final. ${ }^{17}$ The offer must be definite enough to allow a reasonable calculation of damages in the case of breach. ${ }^{18}$ The offer must be final in order to provide a clear signal to the offeree that acceptance will create a binding agreement. ${ }^{19}$ These protections and goals are far removed from the goals of the on-sale bar, which include preventing people from monopolizing part of the public

10. E.g., UMC, 816 F.2d at 653,656 .

11. Id.

12. 525 U.S. 55, 67 (1998); William C. Rooklidge \& Russell B. Hill, The Law of Unintended Consequences: The On Sale Bar Afier Pfaff v. Wells Electronics, 82 J. Pat. \& Trademark OfF. Soc'Y 163, 174-75 (2000) (recognizing that Pfaff eliminated the totality of the circumstances test and suggesting that only a contractual offer may suffice to raise the bar).

13. Group One, Ltd. v. Hallmark Cards, Inc., 254 F.3d 1041, 1046 (Fed. Cir. 2001).

14. See, e.g., Special Devices, Inc. v. OEA, Inc., 270 F.3d 1353 (Fed. Cir. 2001).

I5. Id.

I6. Compare Egbert v. Lippmann, 104 U.S. 333, 339 (1881) (holding that a single use or sale may raise the bar), with Linear Tech. Corp. v. Micrel, Inc., 275 F.3d 1040, 1049 (Fed. Cir. 200I) (holding that extensive "commercialization" falling short of a formal offer does not raise the bar).

I7. See Restatement (SECOND) of Contracts $\$ 33$ (198I) (requiring that terms of an offer be reasonably certain in order to result in a contract upon acceptance); $I d . \S 26$ (defining an offer as the "manifestation of willingness to enter into a bargain").

I8. Id. $\$ 33 \mathrm{cmt}$. b.

19. Id. $\S 24$. 
domain and preventing inventors from unfairly extending the effective length of their patent monopolies. ${ }^{20} \mathrm{~A}$ contractual offer does not serve as a good proxy for a true violation of these policies. ${ }^{21}$

This Comment contends that, in fact, no all-or-nothing rule that relies solely on the conduct of an inventor at a particular point in time will achieve the goals of the on-sale bar. The on-sale bar exists not to punish certam inventor behavior, but to guard against the undesirable consequences of that behavior: disruption of the bargain between a patent holder and the public that is codified in the patent statutes. Any test that considers behavior at a single point in time will fail to reliably minimize these consequences. The law should therefore change to take them into account.

Several approaches are open to Congress or the courts should they decide to modify the law. Either branch could carve out exceptions to the general rule, such as exempting inventors who lack the ability to manufacture or allowing private sales. However, because these exceptions, like the current rule, apply to conduct at a particular point in time, they may add complexity without addressing the basic structural defect.

Instead, Congress could formulate a different basic rule, one that requires courts to consider a broader set of conduct in determining whether to apply the on-sale bar. For instance, Congress might require courts to review the effects of the sale or marketing activity on the public in determining whether to raise the bar. In order to address Pfaff's concern about a vague test, however, any proposed solution should provide more of a bright line than the totality of the circumstances test that $P f a f f$ abrogated. ${ }^{22}$ Thus, any rule that would raise the bar based merely on some marketing activity, or even a certain level of marketing activity, runs the risk of being unacceptably vague. The contractual offer standard, despite its shortcomings, ${ }^{23}$ is grounded in principles of contract law with which the courts have extensive experience. ${ }^{24}$ Furthermore, past decisions provide little clear analysis of what sorts of marketing activities result in unfair competitive exploitation. ${ }^{25}$ Courts may have great difficulty determining when a particular set of actions by an inventor causes substantial harm to the public.

The economic analysis of patent law suggests a better solution. Granting a patent involves balancing the benefit to society from increased incentive for inventors and public disclosure of inventions against the harm

20. See infra Part 11.D.

21. Id.

22. See Pfaff., 525 U.S. at 66 n.11 (1998)

23. See infra Part III.

24. See, e.g., Group One, Ltd. v. Hallmark Cards, Inc., 254 F.3d I041, I047 (Fed. Cir. 2001) (observing that "[c]ourts are quite accustomed to and comfortable with determining whether a particular communication or series of communications amounts to an offer in the contract sense").

25. See infra Part I.B. 
done to society by sanctioning a temporary monopoly. ${ }^{26}$ Like other requirements for patentability, the on-sale bar seeks to preserve the statutory bargain. Cases discussing the on-sale bar have recognized this function and have laid out a partial set of the imbalances that the on-sale bar serves to correct. ${ }^{27}$ This Comment proposes a two-part rule for the on-sale bar that is explicitly remedial in nature.

First, because a pre-filing sale commences the monopoly before commencing the benefits of public disclosure, the appropriate remedy is to bring the two back into alignment by adjusting the dates of the patent term to coincide with the actual period of commercial activity. Second, because pre-filing sales can induce public reliance, the appropriate remedy is to prohibit the assertion of the patent against parties who have reasonably relied. ${ }^{28}$ The economic analysis of this area of the law is still developing. ${ }^{29}$ But even a basic economic analysis illuminates why shifting the dates of the patent term and addressing reliance directly are preferable to an absolute bar.

Part I of this Comment provides a history of the bar, which has evolved mostly through decisions of federal courts. Part II presents a summary of the existing economic analysis of patent law in general and an extension of that analysis to the on-sale bar in particular. Part III assesses the current rule using the framework developed in Part II. Part IV outlines two principal alternate standards, one that would require legislative intervention and one implementable by the courts. In assessing both proposals against the framework developed in Part II, Part IV ultimately demonstrates how both would be improvements over the current rule. Finally, Part V briefly extrapolates the analysis of the on-sale bar to all-or-nothing rules in other areas of law. Because many such all-or-nothing rules share structural characteristics with the on-sale bar, Part V concludes that modified rules similar to the one proposed in this Comment would be helpful in other contexts as well.

26. See generally Robert CoOTer \& Thomas Ulen, LaW \& EConomics 122-32 (4th ed. 2004).

27. See infra Part II.D.

28. See UMC Elecs. Co. v. United States, 816 F.2d 647, 652 (Fed. Cir. 1987).

29. Compare Edmund W. Kitch, The Nature and Function of the Patent System, 20 J.L. \& ECON. 265 (1977) (arguing that efficiency requires granting patents with broad scope), with Mark A. Lemley \& Lawrence Lessig, The End of End-to-End: Preserving the Architecture of the Internet in the Broadband Era, 48 UCLA L. REv. 925, 960-62 (2001) (arguing that free competition led to greater innovation on the Internet). 


\section{BACKGROUND}

\section{A. Origin of the On-Sale Bar}

The original on-sale bar was a judicially created doctrine established by the Supreme Court in Pennock v. Dialogue. ${ }^{30}$ In Pennock, the inventor of a new method of joining rubber hose manufactured and sold substantial quantities of the hose for several years before filing for a patent. ${ }^{31}$ The Court found that the inventor had forfeited his right to a patent on the hose. ${ }^{32}$ The rule stated in Pennock is that an inventor may not obtain a patent "if he suffers the thing invented to go into public use, or to be publicly sold for use" before filing a patent application. ${ }^{33}$

Congress first codified the Pennock holding in the Patent Act of 1836, but in doing so it changed the wording of the rule slightly to "in public use or on sale. ${ }^{.34}$ Congress amended this provision in the Patent Act of I 839 by adding a two-year grace period and limiting the bar to public use or sale authorized by the inventor. ${ }^{35}$ The Patent Act of 1939 changed the grace period from two years to one. ${ }^{36}$

The on-sale bar now appears in the section of the patent statute requiring that inventions must be "novel" in order to be patentable. ${ }^{37}$ In relevant part, the current version of 35 U.S.C. $\S 102$ (b) states, "A person shall be entitled to a patent unless... (b) the invention was... on sale in this country, more than one year prior to the date of the application for patent in the United States." 38

\section{B. The On-Sale Bar in the Regional Circuits}

Following its decision in Pennock, the Supreme Court provided little further guidance as to the definition of "on sale." As a result, the various regional circuits took up the task of defining what activity by an inventor placed a product on sale under $\S 102(\mathrm{~b})$. Early on, courts established that a completed sale is not necessary to invoke the on-sale bar. Rather, it is

\footnotetext{
30. 27 U.S. (2 Pet.) 1 (1829).

31. Id. at $23-24$.

32. Id. at 24 .

33. Id. at 23-24.

34. Patent Act of 1836 , ch. 357, $\$ 6,5$ Stat. 117, 119 (repealed 1870).

35. Patent Act of 1839 , ch. $88, \S \S 6-7,5$ Stat. 353,354 (current version at 35 U.S.C. $\S 102$ (b) $(2000))$.

36. Patent Act of 1939 , ch. $450, \S 1,53$ Stat. 1212 (codified at 35 U.S.C. $\S 102$ (b) (2000)).

37. 35 U.S.C. $\$ 102$ ("Conditions for patentability; novelty and loss of right to patent.").

38. Id. $\$ 102(\mathrm{~b})$.
} 
enough to place the invention "on sale." The regional circuits adopted several different definitions for "on sale."

The First and Second Circuits created the "on hand" doctrine. This strict test required that an invention be "on hand ready to be delivered to any purchaser" in order to fall under $\S 102(\mathrm{~b}) .{ }^{40}$ Although the test was the subject of criticism, some courts continued to apply it until just before the Federal Circuit was established..$^{41}$

The Eighth Circuit devised a different rule, less strict than the "on hand" doctrine, in Bergstrom v. Sears, Roebuck \& $\mathrm{Co}^{42}$ This test required that "(1) the patentee must have had a present intent to sell, and (2) that intent must have been communicated to a prospective purchaser for the purpose of eliciting a sale." ${ }^{33}$ The Bergstrom test, unlike the "on hand" doctrine, did not require that the product be ready for delivery in order to be on sale.

Other circuits, most notably the Seventh Circuit, adopted a more policy-focused test. Judge Learned Hand articulated two of the principal policies underlying the bar in Metallizing Engineering Co. v. Kenyon Bearing \& Auto Parts Co. ${ }^{44}$ The first policy protects the public from patents on inventions already in the public domain. ${ }^{45}$ The second policy prevents the patentee from using his patent to "gain a competitive advantage over others ... [by] extend[ing] the period of his monopoly."46 This second policy applies even when there has been no public disclosure of the invention. ${ }^{47}$ Under the Seventh Circuit test, any "activity by the inventor or his company in attempting to sell the patented idea" might place the product on sale under $\S 102(\mathrm{~b})$, provided that such activities were "found commercially to exploit an invention prior to the critical date." ${ }^{98}$

The Ninth Circuit adopted the Seventh Circuit's test in Robbins Co. v. Lawrence Manufacturing Co. ${ }^{49}$ An often-cited district court case from the Third Circuit emphasized the flexibility of this test by holding that " $t \mathrm{t}] \mathrm{he}$

39. See, e.g., Wende v. Horine, 225 F. 501, 505 (7th Cir. 1915) (holding that " $[\mathrm{t}]$ he statute does not require a 'sale,' but only a placing 'on sale,' prior to two years before the application.").

40. Burke Elec. Co. v. Indep. Pneumatic Tool Co., 234 F. 93, 93 (2d Cir. 1916). See also B.F. Sturtevant Co. v. Mass. Hair \& Felt Co., 124 F.2d 95, 96-97 (1st Cir. 1941) (stating that to prove that a product was on sale, it must have been manufactured or delivered).

41. See, e.g., Forbro Design Corp. v. Raytheon Co., 390 F. Supp. 794 (D. Mass. 1975).

42. 599 F.2d 62 (8th Cir. 1979).

43. Id. at 65 .

44. 153 F.2d 516 (2d Cir. 1946); see also Red Cross Mfg. Corp. v. Toro Sales Co., 525 F.2d 1135,1139 (7th Cir. 1975) (citing Metallizing Eng'g with approval).

45. Metallizing Eng'g, 153 F.2d at 520.

46. Id.

47. See, e.g., id. (holding that an inventor who sells his invention commercially "forfeits his right regardless of how little the public may have learned about the invention").

48. Red Cross Mfg., 525 F.2d at 1139-40 (quoting Amphenol Corp. v. Gen. Time Corp., 397 F.2d 431, 433 (7th Cir. 1968)).

49. 482 F.2d 426, 431 (9th Cir. 1973). 
words 'on sale' themselves imply that the intent of the inventor is the critical factor. It is a question of fact to be determined upon all the evidence and in light of all the circumstances of the case." 50

Thus, at the time of the creation of the Federal Circuit in $1982,{ }^{51}$ at least three definitions of "on sale" existed in the regional circuits.

\section{The On-Sale Bar in the Federal Circuit}

The Federal Circuit opted to establish the flexible, policy-oriented approach that originated in the Seventh Circuit. ${ }^{52}$ The United States Court of Customs and Patent Appeals, one of the predecessors to the Federal Circuit, adopted the Seventh Circuit test in In re Theis. ${ }^{53}$ The Federal Circuit followed In re Theis in Barmag Barmer Maschinenfabrik AG $v$. Murata Machinery, Ltd., holding that attempted commercial exploitation of an invention triggers the on-sale bar. ${ }^{54}$

Then, in UMC Electronics Co. v. United States, the Federal Circuit articulated its "totality of the circumstances" test, drawing from the policyfocused line of cases. ${ }^{55}$ In $U M C$, however, the Federal Circuit further required a "definite sale or offer to sell" in order to raise the on-sale bar. ${ }^{56}$ The patentee in $U M C$, in a letter to the United States government, offered to sell an accelerometer embodying the patented invention more than one year before filing for a patent. ${ }^{57}$ The letter contained price and quantity terms. ${ }^{58}$ Based on the letter, the court found that the patentee had "made a definite offer to sell its later patented UMC-B accelerometer to the Navy more than one year prior to the date of the application for the patent in suit." 59

A subsequent federal circuit case upheld the requirement of a "definite offer to sell." ${ }^{\prime 0}$ In $R C A$ Corp. v. Data General Corp., the patentee submitted a proposal to furnish equipment embodying a patented invention to the Federal Aviation Administration (FAA). ${ }^{61}$ The court found that the FAA "could have 'accepted' RCA's proposal which is the characteristic of a

50. Philco Corp. v. Admiral Corp., 199 F. Supp. 797, 817 (D. Del. 1961).

51. Federal Courts Improvement Act of 1982, Pub. L. No. 97-164, 96 Stat. 25, 36 (codified as amended in scattered sections of 28 U.S.C.).

52. Amphenol, 397 F.2d at 433; Philco, 199 F. Supp. at 817.

53. 610 F.2d 786, 792 (C.C.P.A. 1979) (citing with approval Amphenol, 397 F.2d at 433).

54. 73I F.2d 83I, 839 (Fed. Cir. 1984).

55. 816 F.2d 647, 653-54, 656 (Fed. Cir. 1987) (citing with approval Philco, I99 F. Supp. at $815)$.

56. Id. at 656 .

57. Id. at 657

58. Id.

59. Id.

60. RCA Corp. v. Data General Corp., 887 F.2d 1056, I062 (Fed. Cir. 1989).

61. Id. at 1059 . 
definite formal offer." 62 As a result, there was a definite offer to sell the invention and the patent was thus invalid. ${ }^{63}$

\section{Pfaff v. Wells Electronics}

In Pfaff the Supreme Court replaced the Federal Circuit's "totality of the circumstances" test for the on-sale bar of $\S \mathrm{I02(b)}$ with a two-part rule: "First, the product must be the subject of a commercial offer for sale. . . Second, the invention must be ready for patenting." ${ }^{64}$ In Pfaff, the inventor of a computer chip socket prepared "detailed engineering drawings" that fully disclosed the invention more than a year before filing for a patent. ${ }^{65}$ After showing a sketch of the invention to a prospective purchaser, Pfaff accepted the purchaser's “oral purchase order for 30,100 of his new sockets." 66 The Court found that "[i]n this case the acceptance of the purchase order prior to April 8, I98I [one year before the filing date, the so-called "critical date"], makes it clear that such an offer had been made." Also, "[w] sockets prior to April 8, I98I, his invention was ready for patenting."68

In abrogating the totality of the circumstances test altogether, the Court took a broad view of the question raised in the petition for certiorari, which was whether the on-sale bar could apply "even though the invention [had] not yet been reduced to practice." ${ }^{.99}$ As the Federal Circuit later noted, the question of "what constitutes an offer for sale in the absence of an actual sale" was not squarely implicated in Pfaff..$^{70}$ Pfaff in fact provided little guidance as to the level of conduct needed to qualify as a "commercial offer for sale," arguably implying that the Federal Circuit's requirement of a "definite offer" under $U M C$ and $R C A$ might still be appropriate. $^{71}$

62. Id. at 1062. The Federal Circuit paid particular attention to this language in $R C A$ when it later adopted its contractual offer standard. Group One, Ltd. v. Hallmark Cards, Inc., 254 F.3d 1041, 1046 (Fed. Cir. 2001) (observing that the court in RCA found an "offor in the contract sense").

63. The court in $R C A$ also stated that the requirement of a definite offer "may be met by a patentee's commercial activity which does not rise to the level of a formal 'offer' under contract law principles." 887 F.2d at 1062 . Since the court later found the patentee's offer to meet the contractual standard, though, this statement is arguably dictum, as the Federal Circuit later observed. Group One, 254 F.3d at 1046.

64. Pfaff, 525 U.S. at 67.

65. Id. at 58.

66. Id.

67. Id. at 67.

68. Id. at 68 . The Court, unfortunately, also included in its opinion language suggesting that "commercial marketing," and not only an "offer for sale," might be enough to trigger the bar. $I d$. at 67 . The Federal Circuit rejected this analysis in Group One. See 354 F.3d at 1046.

69. Pfaff, 525 U.S. at 57.

70. Linear Tech. Corp. v. Micrel, Inc., 275 F.3d 1040, 1048 (Fed. Cir. 2001).

71. See id. (observing that the Supreme Court provided "less guidance on the definition of a 'commercial offer for sale'"); RCA Corp. v. Data General Corp., 887 F.2d 1056, 1062 (Fed. Cir. 1989); UMC Elecs. Co. v. United States, 816 F.2d 647, 656 (Fed. Cir. 1987). 


\section{E. Group One v. Hallmark Cards}

After the Supreme Court decided Pfaff, however, the Federal Circuit changed course and began to require a more formal offer to invoke the on-sale bar. In Weatherchem Corp. v. J.L. Clark, Inc., the Federal Circuit noted that Pfaff abrogated the "totality of the circumstances" test and applied a contractual analysis to determine that the on-sale bar was invoked by evidence of a signed purchase agreement before the critical date. ${ }^{72}$ In Rotec Industries v. Mitsubishi Corp., while considering what level of conduct was necessary for patent infringement under 35 U.S.C. $\S 271$ (a), the court noted in dicta that $P f a f f$ indicated that traditional contract law should be the basis for on-sale determinations under $\S 102(\mathrm{~b}) .^{73}$

In Group One, the FederaI Circuit explicitly interpreted Pfaff as requiring that only an offer which "rises to the Ievel of a commercial offer for sale, one which the other party could make into a binding contract by simple acceptance (assuming consideration), constitutes an offer for sale under $\S 102$ (b). ${ }^{174}$ In doing so, the court rejected the language in $R C A$ suggesting that conduct falling short of a contractual offer could trigger the bar and found no other Federal Circuit case law to the contrary. ${ }^{75}$

The test for the on-sale bar has thus evolved from one that considered a broad range of evidence but was difficult to apply consistently to one that is straightforward to apply but considers only a single instance of conduct. As discussed below, the current rule abandons the goals of the patent system for the sake of clarity.

\section{F. Current Problems with the On-Sale Bar}

Following Group One, the Federal Circuit strictly applied the requirement of a contractual offer, with sometimes surprising results. For example, the hypothetical scenarios at the beginning of this Comment were based on two Federal Circuit decisions that applied the contract-based rule. This section provides an in-depth exploration of those scenarios.

\section{Internal vs. Outsourced Manufacturing}

In Special Devices, Inc. v. OEA, Inc., the Federal Circuit held that an invention is on sale under $\S 102$ (b) when the inventor agrees to buy the invention from a third-party manufacturer, even if the inventor has not offered to sell the invention to the public. ${ }^{76}$ In Special Devices, the inventor of a glass component used in automobile airbags entered into two

\footnotetext{
72. 163 F.3d 1326, 1333 (Fed. Cir. 1998).

73. 215 F.3d 1246, 1254-55 (Fed. Cir. 2000).

74. Group One, Ltd. v. Hallmark Cards, lnc., 254 F.3d 1041, 1048 (Fed. Cir. 2001)

75. Id. at 1046 .

76. 270 F.3d 1353, 1354 (Fed. Cir. 2001).
} 
transactions with a supplier before the critical date. ${ }^{77}$ In the first transaction, the inventor placed an order for 20,000 units, with delivery commencing before the critical date. ${ }^{78}$ In the second transaction, the inventor and supplier agreed on terms for a requirements contract, which was implemented after the critical date. ${ }^{79}$ The inventor, as the court noted, lacked the ability to make the parts in-house. ${ }^{80}$

The court rejected the argument that sales from a supplier to an inventor should not raise the bar. ${ }^{81}$ First, the court reasoned that the language of $\S 102$ (b) states only that the invention need be "on sale" in order to raise the bar and does not exclude sales to particular parties. ${ }^{82}$ Second, the court found no binding precedent allowing for a supplier exception, particularly in light of the clear, two-part test in Pfaff. $^{83}$ Finally, the court found the strict application of the bar consistent with the "primary policy" underlying the bar: the policy of "encourag[ing] an inventor to enter the patent system promptly."

The court in Special Devices also explicitly disapproved ${ }^{85}$ of an earlier district court case, M\&R Marking Systems v. Top Stamp, Inc., which found that " $[\mathrm{t}] \mathrm{he}$ purposes of the on-sale bar are not served by applying it to a sale from a manufacturer to the inventor." ${ }^{\text {" } 6 ~}$ These purposes, according to the district court, included preventing commercialization of the invention beyond the term of the patent and preventing public reliance on inventions already apparently in the public domain. ${ }^{87}$ The district court observed that applying the bar to inventors who purchased from manufacturers would simply "penalize inventors who are unable to manufacture their own products." 88 In Special Devices, the Federal Circuit did not explicitly address or justify this difference in treatment. ${ }^{89}$

\section{Aggressive Marketing vs. Formal Contractual Offer}

In Linear Technology Corp. v. Micrel, Inc., the Federal Circuit held that substantial marketing activity that does not rise to the level of a

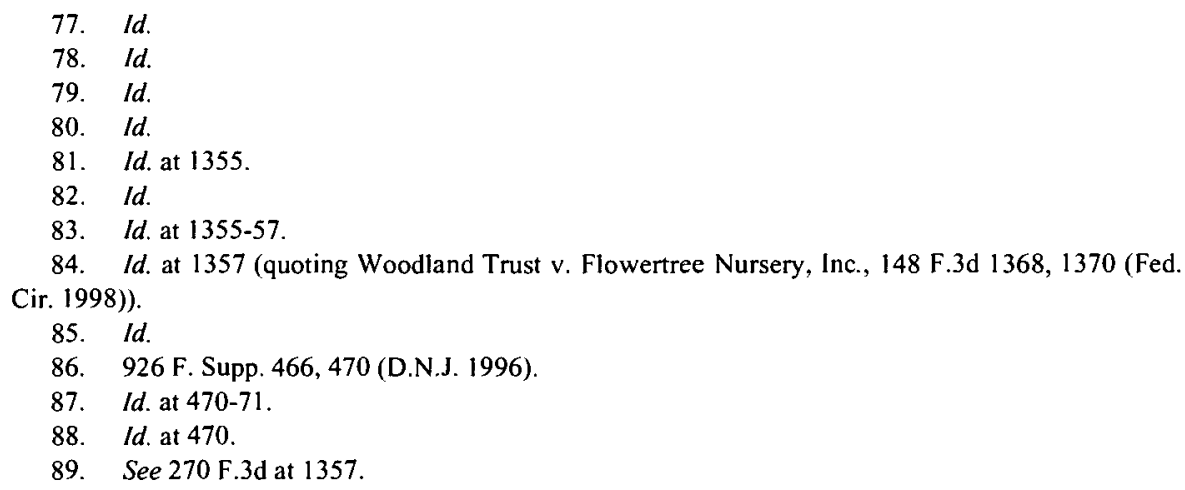


contractual offer does not suffice to trigger the bar. ${ }^{90}$ In Micrel, the holder of a patent on a voltage regulator marketed a device embodying the invention, both in the United States and abroad, before the critical date. ${ }^{91}$ The patentee introduced the regulator to its sales force (composed, in part, of third-party sales representatives who also acted as the patentee's distributors in Europe), engaged in direct customer conversations about the regulator, and presented at least some technical information about the regulator at a sales convention in Europe. ${ }^{92}$ Some of the patentee's customers, intrigued by the product, sent purchase orders to the patentee..$^{93}$ The patentee did not accept the purchase orders, but issued "will advise" notices to the customers. ${ }^{94}$

The court observed, first, that advertising and marketing do not meet the contractual standard for an offer. ${ }^{95}$ The marketing activity by the patentee merely put customers "on notice that [the patentee] will make such offers to sell in the near future-but not today." 96 Second, the court found that the purchase orders received from customers were "offers to buy" the regulator. ${ }^{97}$ Because the patentee made no offers to sell, and because the "will advise" responses that the customers received were not acceptances of their offers to buy, the court found that no offer to sell or sale had occurred. $^{98}$

\section{Summary}

While the rules announced in Special Devices and Micrel may support some of the on-sale bar's justifications, they also produce very different outcomes for parties with arguably very similar conduct, as the opening hypotheticals illustrate. Moreover, in neither case did the court explicitly discuss whether such differences were appropriate. In Special Devices, for instance, the court did not consider how the current rule creates disparate results solely based on manufacturing ability. ${ }^{99}$ In fact, the current rule

90. 275 F.3d 1040, 1052 (Fed. Cir. 2001). This Comment is not alone in its criticism of the result in Micrel. See also Heather Colburn \& Julie VanDerZanden, The On-Sale Bar: Commercial Exploitation Through Competitive Advantage, lNTEll. Prop. Today, Sept. 2002, at 10-11 (suggesting that aggressive marketing should trigger the on-sale bar).

91. Id. at 1044 .

92. Id. at $1044-45$.

93. Id. at 1045 .

94. Id.

95. Id. at 1052 .

96. Id. at 1051 .

97. Id. at 1052 .

98. Id. at 1054 .

99. Special Devices, Inc. v. OEA, lnc., 270 F.3d 1353. This difference in treatment is likely to result in inefficient "sham" transactions by corporations, in order to make the sale internal. Under recent analyses of the corporate form, particularly those that employ transaction-cost economics, no meaningful distinction necessarily exists between intrafirm and interfirm transactions. See generally 
precludes such comparisons; as Judge Michel observed in Special Devices, satisfying the two prongs of the Pfaff test ends the inquiry. ${ }^{100}$

Although the cases described here illustrate two divisions inherent in the current rule, others may exist. The next section examines the economic rationales underlying the bar to explore more systematically why the current rule is not well-suited to its purpose.

\section{II}

\section{The Economic Basis of Patent Protection}

The economic analysis of patent law springs from the observation that information, such as that disclosed in a patent, has the characteristics of a public good. ${ }^{101}$ First, information is nonrivalrous; one person's use of the information does not diminish its availability to others. ${ }^{102}$ Second, information is non-excludable; one may not easily prevent others from using it, once it is publicly available, since the transmission of an invention from one party to another is cheap. ${ }^{103}$ In contrast, physical goods are generally both rivalrous and exclusive. ${ }^{104}$

To illustrate the difference, imagine that an inventor builds a better lawnmower, which he rents out to his neighbors. The lawnmower itself, a physical good, is rivalrous since the inventor can rent it out to only one neighbor at a time, and exclusive since the inventor can prevent his neighbors from using it by keeping it locked in his garage. The design for the lawnmower-the invention-is nonexclusive because the inventor's neighbor can easily pass it on to another party once the inventor has loaned out the lawnmower. The invention is also nonrivalrous, because one neighbor's use of the lawnmower's design does not prevent another neighbor from using it. Both neighbors may simultaneously build lawnmowers according to the invention and benefit from the improved design.

The economic justification for the patent system relies on the uncontrollable nature of publicly divulged information. ${ }^{105}$ Producing a patentworthy invention requires considerable time and expense. ${ }^{106} \mathrm{~A}$ patent rewards the inventor of a significant invention with a temporary monopoly on the use of the invention. ${ }^{107}$ Armed with the monopoly, the inventor may

\footnotetext{
Alan J. Meese, Intrabrand Restraints and the Theory of the Firm, 84 N.C. L. REv. (forthcoming December 2004).

100. Special Devices, 270 F.3d at 1355 (observing that finding a contractual offer to sell an invention that is ready for patenting "would ordinarily end the two-part analysis under section 102(b)").

101. COOTER \& ULEN, supra note 26 , at 120.

102. Id.

103. Id.

104. Id.

105. Id. at 122 .

106. Id. Not all inventions are patentable. To reeeive a patent, an invention must be useful, novel, and nonobvious. 35 U.S.C. $\S 101-103$ (2000).

107. Id.
} 
earn more than the market rate of return on the invention. ${ }^{108}$ Granting a monopoly, though, necessarily harms society since a monopolist will supply fewer of a patented good and charge more for a patented good than she would under perfect competition. ${ }^{109}$

\section{A. The Benefits of Granting a Patent}

Both the patentee and society at large benefit from patents. The patentee benefits directly from the patent-provided monopoly by commercializing the invention. ${ }^{10}$ Commercializing an apparatus-type invention requires either that the inventor herself manufacture products embodying the invention or that she license others to do so. "' Similarly, commercializing a process-type invention requires either that the inventor perform the process for compensation, or that she license someone else to do the same. ${ }^{112}$ The patentee also benefits from the monopoly to the extent that use of the invention is important to future research. In order to make use of the inversion, other researchers may be required to pay a license fee.

The length of the patent term has a direct relationship to the magnitude of the patent's benefits. ${ }^{113}$ Once the patent expires, the inventor is no longer able to charge a monopoly price for the invention since competitors will enter the market and lower the price. Nor may an inventor collect licensing fees after a patent has lapsed. ${ }^{114}$

Society reaps only an indirect benefit from the monopoly: increased inventive activity encouraged by the possibility of monopoly profits. ${ }^{15} \mathrm{~A}$ faster rate of invention benefits society by causing new and better products and services to come to market sooner. ${ }^{116}$ Better products and services lead to greater productivity, which in turn contributes to wealth. ${ }^{117}$ Society also benefits because the inventor must disclose the invention in order to receive a patent. ${ }^{118}$ The disclosure allows other inventors to build upon and

\footnotetext{
108. Id.

109. Id.

110. Id.

111. See id. at 122-24 (describing the ability of a patent holder to obtain monopoly profits or to obtain royalties from licensing).

112. See id.

113. See generally Robert P. Merges \& Richard R. Nelson, On the Complex Economics of Patent Scope, 90 Colum. L. REV. 839, 868-70 (1990) (acknowledging the relationship between patent scope, both in terms of breadth and duration, and patent value); see also WiLliam D. Nordhaus, INVENTION, GROWTH, AND WELFARE (1969) (describing the relationship between patent term and patent value).

114. Extending a licensing agreement beyond the term of a patent is patent misuse. See, e.g., Brulotte v. Thys, 379 U.S. 29, 32 (1964).

115. COOTER \& ULEN, supra note 26, at 122.

116. Merges \& Nelson, supra note 113, at 878-79.

117. Id. According to Merges and Nelson, advances in technology are linked to increases in productivity, or the measure of per-person eeonomic productivity. $I d$. Since money has time value, the faster productivity rises, the greater the economic benefit. $l d$.

118. 35 U.S.C. $\S 112(2000)$. The inventor must disclose the invention in sufficient detail to enable one of ordinary skill in the art to construct or reproduce it. $/ d$.
} 
further improve the invention. ${ }^{119}$ Without the protection of a patent, inventors would be required to keep their inventions secret in order to realize monopoly profits; this secrecy would hamper the inventive efforts of others.

\section{B. The Costs of Granting a Patent}

Granting a patent also harms society on a number of levels. Certain harms flow directly from the patent monopoly itself. ${ }^{120}$ Most early economic analyses of patent law considered only these direct harms. ${ }^{121}$ A second class of harms springs from the effect of the patent system on the behavior of inventors. ${ }^{122}$ These indirect harms arise because inventors may engage in inefficient strategic behavior in pursuit of a patent monopoly. ${ }^{123}$

The patent monopoly directly harms society by allowing the patented good to be sold at an inflated price. ${ }^{124}$ In order to sell the good at a higher price, a monopolist will produce fewer of the patented good than society demands. ${ }^{125}$ Since patented goods, by definition, do not have good close substitutes, part of society will be deprived of the benefits of the patented invention. ${ }^{126} \mathrm{~A}$ patent also prevents other inventors from creating new products that are improvements of the patented product. ${ }^{127}$ Since the patentee has the right to exclude anyone from using her invention, other inventors may not create products based on the patented product without the permission of the patentee. ${ }^{128}$ The result is slower innovation in the field of the patented invention and thus deferred benefit to society.

Patents create indirect harms by spurring inventors to work competitively rather than collaboratively. Inventors inefficiently duplicate efforts as they and their organizations race to be the first to invent in order to secure a monopoly. ${ }^{129}$ Also, as with any system that awards property rights

\footnotetext{
119. Merges \& Nelson, supra note 113, at 878.

120. COOTER \& ULEN, supra note 26 , at 122 .

121. Merges \& Nelson, supra note 113, at 868 .

122. Id. at 869 .

123. Id.

124. COOTER \& ULEN, supra note 26 , at 122.

125. Id.

126. Id,

127. Id. at 125; Merges \& Nelson, supra note 113 , at 870 .

128. Of course the patentee may license other inventors to use the patented product in their research. Even so, the cost of the license acts as a "tax" on development in the field of the patented invention. Empirical research also demonstrates that the transaction costs associated with licensing arrangements are quite high. See, e.g., Farok J. Contractor, 1nternational Technology Licensing: Compensation, Costs, ANd Negotiation 104-05 (1981).

129. See COOTER \& ULEN, supra note 26, at 125 (noting that broad patent protection encourages "fast, duplieative research"); Merges \& Nelson, supra note 113, at 870 (describing the effort of many parties to patent the same invention as "overfishing" in the patent pool); see also Mark A. Lcmley \& Kimberly A. Moore, Ending Abuse of Patent Continuations, 84 B.U. L. Rev. 63, 79-80 (2004) (discussing the practice of keeping "submarine" patents mired in the Patent and Trademark Offiee (PTO) in order to delay their issuance until the technology has become commercially viable).
} 
to the "finder," the patent system may cause excessive investment in technologies that are not yet commercially viable, but that will become commercially viable at some point during the term of the patent. ${ }^{130}$

Limiting the length of the patent term places a boundary on the direct harms that a patent may cause. Once the patent has expired, the patented product will be made available at the market price, and inventors will be free to create new inventions that incorporate the patented product. ${ }^{131}$ Limiting the length of the patent term also reduces the indirect harm caused by duplicative inventive effort by reducing the reward associated with obtaining a patent. ${ }^{132}$ With less potential reward at stake, companies will be more reluctant to make large investments in running a race that they may lose.

\section{Balancing Costs and Benefits}

A patent should expire at the point where the marginal costs and benefits of extending the patent term are equal. ${ }^{133}$ In general, the marginal incentive benefit from extending the term of a patent will decrease over time, once an inventor has recovered the cost of invention through monopoly-derived profits. The cost, though, tends to steadily increase since, absent perfect substitutes, some portion of the public will continue to be deprived of the patented invention and improvements thereof. ${ }^{134}$ The current patent term, fixed by statute, is twenty years from the date of filing the patent application. ${ }^{135}$

130. See COOTER \& ULEN, supra note 26, at 146 (noting that any rule of assigning property rights based on first possession tends to lead to "over-investment in the activities that the law defines as necessary to obtain legal possession").

131. See id. at 127 (noting the dramatic drop in price that occurs when formerly patented drugs are offered in generic versions).

132. Id. at 128 .

133. Id. at 128 .

134. The Supreme Court has recognized this goal of balancing costs and benefits. See, e.g., Bonito Boats, Inc. v. Thunder Craft Boats, Inc., 489 U.S. 141, 146 (1989) ("The Patent Clause itself reflects a balance between the need to encourage innovation and the avoidance of monopolies which stifle competition without any concomitant advance in the 'Progress of Science and useful Arts."').

135. 35 U.S.C. $\S 154(a)(2)(2000)$. If twenty years is the optimal length of patent term for a particular invention, it is only by coincidence. First, there has heen little, if any, empirical research into the optimal length of patent protection. See Mark A. Lemley, An Empirical Study of the Twenty-Year Patent Term, 22 AIPLA Q.J. 369, 416-17 (1994) (noting the theoretical, rather than empirical, nature of research on the optimal patent term). Second, as many have observed, the optimal length of patent protection necessarily varies from industry to industry, and also from invention to invention. See, e.g., $i d$; COOTER \& ULEN, supra note 26, at 127-29. This Comment assumes, without loss of generality, that the statutory term is, or could be, optimal. Since the on-sale bar is primarily targeted at ensuring that inventors do not deviate from the prescribed statutory balance, the correct rule for applying the bar is the same no matter what length of time Congress chooses. 


\section{An Economic Analysis of the On-Sale Bar}

The model proposed for the on-sale bar in this Comment, like other economic models of legal rules, assumes that the goal of patent law is to minimize social costs. ${ }^{136}$ The on-sale bar helps to minimize the costs associated with advancing technology by preventing deviations from the statutory bargain codified in the patent laws: a twenty-year monopoly in exchange for providing the public with a significant invention. For instance, a proper rule for the on-sale bar minimizes the cost associated with inventors who fail to apply for a patent on an invention already being used in commerce. ${ }^{137}$ Critical to the analysis that follows is the recognition that the efficiency of the on-sale bar has nothing to do with the length of the patent term chosen by Congress, but only the ability of inventors to manipulate the length of the term. The model proposed in this Comment divides the possible societal harm into five elements related to the disruption of the statutory balance, enumerated below, and a sixth element, which is the administrative cost of enforcing the bar.

\section{The Social Costs Associated with Pre-filing Sales of a Later-Patented Invention}

\section{a. Costs from Disruption of the Statutory Balance}

Several social costs can arise from a delay between placing an invention on sale and filing for a patent. First, an inventor may upset the prescribed statutory balance by exploiting the value of an invention, as a monopolist, prior to obtaining a patent. The inventor may be able to keep the invention secret while commercially exploiting its value, thus preventing competition. ${ }^{138}$ Even if the technology may not be kept secret once commercial exploitation begins, an inventor may still be able to enjoy monopoly power during the time it takes for competitors to reverse engineer or prepare to produce the invention. ${ }^{139}$ Were the inventor allowed to sell the invention for an unlimited period of time before filing, she could unilaterally extend the patent monopoly for as long as she could maintain market control.

136. See generally id. at 320 (characterizing the goal of tort law as minimizing the social cost of accidents); $i d$. at 470 (characterizing the goal of criminal law as minimizing the social cost of crime).

137. See Metallizing Eng'g Co. v. Kenyon Bearing \& Auto Parts Co., 153 F.2d 516, 520 (2d Cir. 1946) (holding that "it is a condition upon an inventor's right to a patent that he shall not exploit his discovery competitively after it is ready for patenting; he must content himself with either secrecy, or legal monopoly").

138. For example, an inventor of a cheaper process for making a nonpatented product will be able to manufacture the product at a lower cost than its competitors without disclosing the details of how the process works. See, e.g., Kewanee Oil Co. v. Bicron Corp., 416 U.S. 470, 481-82 (1974) (noting the incentive to invention provided by trade secrets).

139. See, e.g., Mark A. Lemley \& David W. O'Brien, Encouraging Software Reuse, 49 Sran. L. REv. 255, 274-75 (1997) (discussing the ability of an inventor to capitalize on being the "first mover" in a market, regardless of patent protection). 
Second, the consuming public may come to rely on the invention being available without a patent attached. ${ }^{140}$ This reliance may cause harm to those consumers if the inventor raises the price after securing a patent. ${ }^{141}$

Third, other inventors may suffer an additional harm if they invest in research that depends on the invention. ${ }^{142}$ Once the patent issues, the patentee will be able to block any additional research and may cause the work of the other inventors to go to waste. ${ }^{143}$

Fourth, a delay in filing a patent is itself harmful if the inventor keeps the invention a secret. An invention benefits society both by increasing current productivity and by providing a basis for future innovation. ${ }^{144}$ Future innovation cannot begin, though, until the invention is disclosed. Any delay to the public disclosure accompanying a patent application is thus a deferral of the benefit to be realized from future discoveries springing from the invention.

Fifth, a delay in filing may prolong duplicate research by other inventors if the sale does not reveal to the competing inventors that they have already lost the race to develop the invention. ${ }^{145}$

Not all of these harms occur in each case. For example, the actual economic consequences of placing an invention on sale depend in part on whether the invention was disclosed to the public as a result of the sale. If the invention was disclosed, then a delay in filing does not hamper invention inspired by the new technology or prolong duplicative invention efforts. If the invention was not disclosed, then a delay in filing cannot have the effect of inducing other inventors to create improvements. Finally, whether or not the invention was disclosed, the sale may result either in the inventor unilaterally extending the benefit of the monopoly or the public coming to rely on the result of the invention being available at a low price. $^{146}$

140. UMC Elecs. Co. v. United States, 816 F.2d 647, 652 (Fed. Cir. 1987); Metallizing Eng'g Co. v. Kenyon Bearing \& Auto Parts Co., 153 F.2d 516, 520 (2d Cir. 1946).

141. This is particularly true where forces such as network effects or de facto standards compel subsequent consumers to purchase the higher-priced product. Mark R. Patterson, Inventions, Industry Standards, and Intellectual Property, 17 BERKELEY TECH. L.J. 1043 (2002).

142. Recognition of this particular form of reliance is lacking in existing analysis of commentators and the courts. See infra note 155 and accompanying text.

143. Merges \& Nelson, supra note 113 , at 870-71.

144. See, e.g., Suzannc Scotchmer, Standing on the Shoulders of Giants: Cumulative Research and the Patent Law, 5 J. ECON. PERSP. 29 (1991).

145. Merges \& Nelson, supra note 113, at 870-71.

146. Note that these last two possibilities conflict with each other and are unlikely to occur simultaneously. General public reliance on the invention will only be harmful if the inventor charges less than the monopoly price for the invention before filing for a patent. But the inventor cannot fully reap the benefit of the monopoly without charging the monopoly price. Thus, delaying a patent application will either allow the inventor to unilaterally extend the monopoly or will harm the general public through detrimental reliance, but not both. 
The following chart summarizes the possible negative consequences of placing an invention on sale before filing for a patent. The rule triggering the on-sale bar should be tailored to minimize these consequences.

\begin{tabular}{|l|l|l|l|}
\hline $\begin{array}{c}\text { Negative } \\
\text { Consequence }\end{array}$ & $\begin{array}{l}\text { Invention } \\
\text { Disclosed? }\end{array}$ & \multicolumn{1}{|c|}{$\begin{array}{c}\text { Affected } \\
\text { Parties }\end{array}$} & \multicolumn{1}{|c|}{ Type of Effect } \\
\hline $\begin{array}{l}\text { (1) Extension } \\
\text { of monopoly }\end{array}$ & Either & $\begin{array}{l}\text { Consumers and } \\
\text { other inventors }\end{array}$ & $\begin{array}{l}\text { Additional period of } \\
\text { undersupply of invention and } \\
\text { inability to freely create } \\
\text { improvements to invention }\end{array}$ \\
\hline $\begin{array}{l}\text { (2) Reliance } \\
\text { by consumers }\end{array}$ & Either & Consumers & $\begin{array}{l}\text { Consumer preferences develop } \\
\text { based on false expectations of } \\
\text { being able to obtain the } \\
\text { invention at a low price }\end{array}$ \\
\hline $\begin{array}{l}\text { (3) Reliance } \\
\text { by inventors }\end{array}$ & Yes & Other inventors & $\begin{array}{l}\text { Inventors may engage in } \\
\text { research that will be enjoined or } \\
\text { taxed once the patent issues }\end{array}$ \\
\hline $\begin{array}{l}\text { (4) Delay in } \\
\text { filing and } \\
\text { disclosure }\end{array}$ & No & Consumers & $\begin{array}{l}\text { Delays development of } \\
\text { derivative products and services } \\
\text { in the field of the invention }\end{array}$ \\
\hline $\begin{array}{l}\text { (5) Increased } \\
\text { duplicate } \\
\text { inventive } \\
\text { effort }\end{array}$ & No & Other inventors & $\begin{array}{l}\text { Allows duplicate research to } \\
\text { continue until the other } \\
\text { researchers learn of the patent }\end{array}$ \\
\hline
\end{tabular}

\section{b. Administrative Costs}

In addition to the costs associated with the disruption of the statutory balance, the administration of the bar exacts costs as well. The three parties most affected by administrative costs are the courts, the patentee, and the Patent and Trademark Office (PTO).

The courts must bear the burden of litigation brought to seek invalidation of patents based on the on-sale bar. The total cost to the courts is a function of two variables: the frequency with which on-sale bar claims arise and the cost of resolving each claim. ${ }^{147}$

The patentee will expend effort circumventing the bar in order to extend the valuable patent monopoly. The particular rule in force dictates the nature of any attempt at circumvention; under the current rule an inventor may spend money on market research and advertising rather than simply offering the invention for sale to the public. ${ }^{148}$

147. For an analogous trade-off in the context of products liability, see COOTER \& ULEN, supra note 26 , at 343 (observing that a rule of strict liability may result in more lawsuits, but that each lawsuit will involve a less complicated burden of proof).

148. See, e.g., Linear Tech. Corp. v. Micrel, Inc., 275 F.3d 1052, 1052 (Fcd. Cir. 2001). 
Since the PTO holds primary responsibility for determining whether a patent should issue, a patent examiner must evaluate each application for potential on-sale bar violations so long as a violation of the bar absolutely defeats the inventor's right to a patent. ${ }^{149}$ This evaluation will vary in cost depending on the complexity of the rule.

Any rule for the on-sale bar also creates some administrative costs due to error, either on the part of the patentee or the PTO. Particularly under an indefinite rule, such as the totality of the circumstances test, the patentee wastes effort pursuing patents that the PTO or a court may subsequently invalidate. ${ }^{150}$ The PTO wastes effort reviewing and issuing patents that a court later invalidates. ${ }^{151}$ Finally, an inventor may be denied a patent that he deserved.

To minimize these administrative costs, any rule for the on-sale bar should be clear and definite, difficult to circumvent, and unattractive as an offensive weapon for litigants.

\section{Economic Analysis by the Courts}

Courts interpreting the on-sale bar have recognized many of these economic consequences, though generally not all in a single case. In Metallizing Engineering Co. v. Kenyon Bearing \& Auto Parts Co., the Second Circuit observed that a sale by an inventor may forfeit the right to a patent in two ways: by "abandon[ing]" the invention to the public or by "coinpetitive exploitation" of the invention too long before the filing date. ${ }^{152}$ While discussing abandonment, the court stated that in "renouncing the right the inventor irrevocably surrenders it," and thus suggested that the on-sale bar protects against detrimental public reliance. ${ }^{153}$ The court also characterized "competitive exploitation" as "extend[ing] the period of [the patentee's] monopoly." 154 These two methods of losing the right to a patent correspond to consequences one through three in the preceeding table. ${ }^{155}$

The Federal Circuit enumerated, in UMC Electronics Co. v. United States, a more complete set of potential negative effects. ${ }^{156}$ The court first noted the risk of "removing inventions from the public which the public has justifiably come to believe are freely available to all as a consequence

149. Manual Of Patent Examining Procedure $§ 706.02$ (8th ed., rev. 1, 2003).

150. The Supreme Court focused on this concern in Pfaff, noting that the indefinite standard employed by the Federal Circuit "seriously undermine[d] the interest in certainty" underlying the onsale bar. Pfaff v. Wells Elecs., Inc., 525 U.S. 55, 65-66 \& n.l 1 (1998).

151. See id.

152. 153 F.2d 516, 520 (2d Cir. 1946).

153. Id.

154. Id.

155. The courts have generally not distinguished between reliance by consumers and reliance by other inventors. See infra note I58 and accompanying text.

156. 816 F.2d 647, 652 (Fed. Cir. I987). 
of prolonged sales activity." 157 This statement reflects the same concern about public reliance that the Second Circuit raised in Metallizing Engineering, making no distinction between consumers who might rely on the invention's price and inventors who rely only on the lack of a patent. ${ }^{158}$

Next, the Federal Circuit noted the "policy favoring prompt and widespread disclosure of new inventions to the public."159 The court did not discuss whether making the invention generally known in conjunction with the sale would avoid this requirement. ${ }^{160}$ The third negative effect, according to the Federal Circuit, was that the inventor may "commercially [exploit] the exclusivity of his invention substantially beyond the statutorily authorized 17-year period." 161 This consequence is identical to that stated in Metallizing Engineering and is listed as consequence one in the table above. ${ }^{162}$

The $U M C$ court articulated a fourth, administrative concern: the patentee needs to have sufficient time to determine the commercial viability of an invention before deciding to file for a patent. ${ }^{163}$ As the court noted, "[t]his benefits the public because it tends to minimize the filing of inventions ... of only marginal public interest," which presumably places an unnecessary burden on the PTO. ${ }^{164}$

Most recently, in Pfaff $v$. Wells Electronics, the Supreme Court restated the two concerns articulated in Metallizing Engineering, observing that $\S 102(b)$ is concerned with "excluding ideas that are in the public domain from patent protection and confining the duration of the monopoly to the statutory term." 165 The Supreme Court discussed administrative costs as well, first observing "the interest in certainty" underlying the on-sale bar. ${ }^{166}$ A definite rule prevents inventors from filing patent applications that will later be rejected by the PTO or the courts. ${ }^{167}$ Second, the Court characterized the "totality of the circumstances" test as "unnecessarily vague," reflecting the same concern with certainty and suggesting that the rule placed an undue burden on the courts. ${ }^{168}$

In sum, courts have identified, with some particularity, the majority of the costs potentially caused by the sale of an invention before a patent has been issued. For most of its history, the on-sale bar has evolved to be more

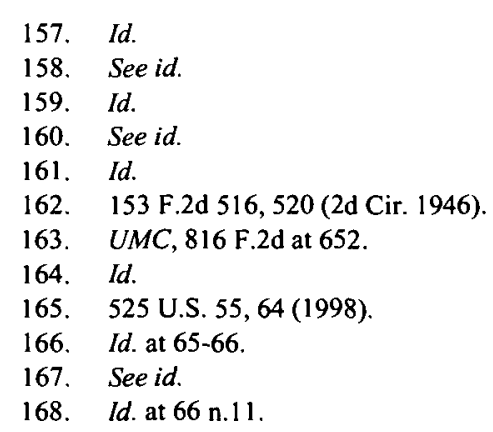


tailored to minimize the costs associated with disruption of the statutory monopoly. ${ }^{169}$ The Federal Circuit's totality of the circumstances test, adopted in $U M C$, was less formalistic and more consequence focused than any of its predecessors. ${ }^{170}$ The rule in Pfaff and Group One reverses this trend and is dramatically narrower than its predecessor. This narrowness adds clarity and reduces administrative cost, but prevents the rule from adequately addressing the economic goals of the on-sale bar.

\section{III}

\section{An Economic Assessment of the Current Standard}

To what extent does raising the on-sale bar at the point when the invention is the subject of a contractual offer for sale minimize each of the social costs discussed above? As shown in the following discussion, the current rule is too strict in some cases, precluding patents when no harm exists, and too lenient in others, allowing patents when harm is evident.

\section{A. Monopoly Extensions}

Triggering the on-sale bar upon a contractual offer does limit an inventor's ability to extend the monopoly period. The inventor may not receive actual compensation for the invention, which would be the result of a completed sale. Nor may the inventor make a binding commitment to sell the invention, which is the hallmark of a contractual offer. ${ }^{171}$ The inventor's inability to commit may discourage potential customers, especially those who must take potentially wasted preparatory steps in order to use the invention. Despite the rule's deterrent effect, it is suboptimal. The hypothetical involving Sumo, Inc.'s mass marketing campaign illustrates how the current rule fails to prevent economic overexploitation in all cases. ${ }^{172}$ The current rule allows-even invites-companies to aggressively market their inventions in ways that do not create a binding offer. Inventors may be able to use aggressive marketing to build up advance demand for an invention, particularly if the inventor has an established market presence and a good reputation. If the advance demand amplifies initial sales volume, then the inventor will have increased the

169. See generally R.J. Barrett, Note, New Guidelines for Applying the On Sale Bar to Patentability, 24 STAN. L. REV. 730 (1972).

170. See UMC Elecs. Co. v. United States, 816 F.2d 647, 656 (Fed. Cir. 1987) (holding that "[a]11 of the circumstances surrounding the sale or offer to sell . . must be considered and weighed against the policies underlying section 102(b)"). In comparison, even the broad test adopted by the Seventh Circuit, raising the bar if the inventor is "found commercially to [have] exploit[ed] an invention prior to the critical date," focuses the analysis on only one of the potential harms caused by placing the invention on sale. Red Cross Mfg. Corp. v. Toro Sales Co., 525 F.2d 1135, 1140 (7th Cir. 1975) (citing Amphenol Corp. v. Gen. Time Corp., 397 F.2d 431, 433 (7th Cir. 1968)).

171. See, e.g., Restatement (SECOND) OF Contracts $\$ 24$ (1981).

172. See supra introduction. 
value of the monopoly because earlier sales have a higher time value than later sales. Inventors may also increase their total sales volume by aggressive marketing if they can persuade potential customers to wait for the release of the invention. Aggressive marketing may also be inefficient. In some cases, actual sales of the invention may be the best way of stimulating interest, particularly when the customer will need to see the invention in action before buying it in bulk. Under the current rule, the inventor has an incentive to convince potential customers by other means.

In addition to failing to prevent certain extensions of the monopoly, the current rule raises an absolute bar to patentability in cases where the inventor has overstepped the statutory monopoly even by a negligible amount. Sam, the garage inventor who unsuccessfully tries to sell his invention to his neighbor, does not have the financial resources or the marketing expertise to capitalize on his invention. ${ }^{173}$ Unlike Sumo, Sam's capacity to create harm is negligible. The current rule encourages circumvention by the inventors who can produce the most harm through their unchecked monopoly power: large companies, such as Sumo, with marketing expertise and substantial financial resources.

\section{B. Consumer Reliance}

In one sense, the point at which an invention becomes the subject of a binding offer is a good proxy for the beginning of public reliance. Until the seller of the invention is willing to be bound, the public cannot safely or reasonably rely on being able to obtain the invention, much less at a particular price.

However, a binding offer does not always trigger consumer reliance. The link between a contractual offer and public reliance does not exist when the invention is offered to someone other than a member of the consuming public. When the consumer is the inventor, as is the case with an inventor's contract with a manufacturer, there is no risk of harmful reliance because the only party purchasing the invention has control over the invention's sale price. ${ }^{174}$

The current rule results in the bar being raised even under these circumstances, as illustrated by Special Devices. ${ }^{175}$ Though the court referred to the inventor's "commercial stockpiling," another, nearly identical

173. See supra Introduction.

174. Nor does the manufacturer supplying the invention to the inventor derive benefit from an extension of the patent monopoly. Since a manufacturer may only make the invention with the permission of the inventor, the inventor is free to choose whichever manufacturer charges the lowest price. If the market for manufacturing services is competitive, the inventor will thus be able to obtain the invention at the market price. If, on the other hand, the market for manufacturing services is not competitive, then the inventor will pay a higher price to have the invention manufactured regardless of whether a patent later issucs.

175. Spccial Devices, Inc. v. OEA, Inc., 270 F.3d 1353, 1354 (Fed. Cir. 2001). 
inventor with the ability to manufacture the invention in-house could engage in the same amount of stockpiling without running afoul of the bar. ${ }^{176}$ The failure of the current rule with respect to the policy of preventing consumer reliance is thus not that the rule is ineffective in doing so, but that it extends, arbitrarily, to other cases where consumer reliance is not possible.

\section{Inventor Reliance}

As indicated by the chart in Part II.D.1, the concern that other inventors will waste resources improving an invention that later receives a patent only arises when the inventor discloses the invention to the public as a result of placing it on sale. Since the current rule raises the bar even when the sale has not disclosed the invention, it applies even when other inventors have not relied to their detriment as a result of the sale. ${ }^{177}$ As a corollary, an inventor may disclose an invention to others in the community without placing it on sale. ${ }^{178}$ Since such disclosure does not involve a contractual offer, under the current rule the bar is not raised.

One might argue that a binding contractual offer, which must be sufficiently definite, will almost always contain information about the invention and is therefore likely to induce reliance by other inventors. Trade secret law makes this argument highly suspect since products embodying trade secrets often manage to keep those secrets hidden from the public even when widely available. ${ }^{179}$ Moreover, courts have long considered the possibility of an invention being on sale without disclosure of the invention to the public. ${ }^{180}$ The presence of a contractual offer is a poor proxy for public disclosure, and thus a poor indicator of detrimental reliance by other inventors.

\section{Delayed Filing and Disclosure}

The current rule provides a strong incentive to file for a patent, thereby disclosing the invention, within a year of the first sale. But because the first sale may occur long after the beginning of the commercial

176. Id. at 1357.

177. See Metallizing Eng'g v. Kenyon Bearing \& Parts Co., 153 F.2d 516, 520 (2d Cir. 1946) (observing that the sale of an invention in violation of the on-sale bar "forfeits [the] right [to a patent] regardless of how little the public may have learned about the invention").

178. An inventor may, in fact, notify others of the invention without running afoul of any of the other requirements of $\S 102(\mathrm{~b})$, which bar patentability only if the invention was publicly used or described in a printed publieation. Telling other inventors about an invention, orally, by itself escapes $\S$ 102(b) altogether. E.g., In re Klopfenstein, No. 03-1583, 2004 WL 1837586, at *3 n.4 (Fed. Cir. Aug, 18, 2004).

179. See generally Kewanee Oil Co. v. Bicron Corp., 416 U.S. 470, 474-75 (I974) (describing a trade secret as information that "gives [the holder] opportunity to obtain an advantage over competitors who do not know or use it" (emphasis added)).

I80. See, e.g., Metallizing Eng'g, 153 F.2d at 518-19 (citing numerous cases considering the effect of sales of "concealed" inventions). 
exploitation of the invention, requiring an inventor to file for a patent within a year of the first sale may not succeed in properly limiting the resulting patent's scope. In addition, the distinction between general commercial activity and a definite offer under the current standard creates an incentive for the inventor to engage in marketing activity beyond the point where it ceases to be efficient to do so. ${ }^{181}$ By prolonging the marketing period, the inventor delays providing the invention to the public, in direct conflict with the policy of timely disclosure. ${ }^{182}$

In other cases, the current rule may provide too strong an incentive to file quickly for a patent. An inventor under the current rule has no choice but to file for a patent within a year of the first sale. Even if the invention experiences little commercial success in its first year on the market, an inventor may seek to file a patent rather than take the risk of losing his right altogether. Large institutional inventors such as IBM are particularly likely to file for patents as a matter of routine. ${ }^{183}$ The problem with rushing to file is that an invention may turn out to be commercially worthless, and a single year of marketing may not provide enough information to determine a patent's worth. The vast preponderance of worthless patents is well documented. ${ }^{184}$ The huge volume of patent applications places great burdens on the PTO ${ }^{185}$ By forcing inventors to choose between obtaining a patent and losing the right to a patent altogether, the current rule tends to exacerbate this problem. ${ }^{186}$

\section{E. Redundant Inventive Effort}

Any delay in disclosing the invention also increases the effort lost in duplicate research. Given that eighteen months may pass under current Iaw before a filed patent application is published, any additional delay may be quite costly. ${ }^{187}$

\section{F. Administrative Costs}

Under the current rule, as the Federal Circuit observed in Group One, the courts face the relatively well-defined task of deciding whether the

181. See supra Part 111.A.

182. As discussed in more detail infra Part 1V.B.4, making changes to the remedial scheme for patent infringement allows for more direct fine-tuning of the incentive to file.

183. See 1BM CoRP., Intellectual Property \& Licensing: Patcnts, at http://www.ibm.com/ibm/ licensing/patents/ (last visited Apr. 10, 2004) (noting that "1BM has about 23,000 active U.S. patents with more being added every week").

184. See, e.g., Mark A. Lemley, Rational lgnorance at the Patent Office, 95 Nw. U. L. Rev. 1495 , 1497 (2001) (noting that "the vast majority of patents . . are never litigated or licensed").

185. See id.

186. Cf. Kewanee Oil Co. v. Bicron Corp., 416 U.S. 470, 488 (1974) (noting that the abolition of trade secrets would put pressure on inventors to secure patents, even if attempting to do so ultimately proved to be a waste of time and resources).

187. 35 U.S.C. $\$ 122$ (b)(1)(A) (2000). 
patentee's conduct rose to the level of a formal contractual offer. ${ }^{188}$ The simplicity of the current rule should reduce administrative costs each time courts apply it instead of the vaguer $U M C$ standard. ${ }^{189}$ On the other hand, because the rule is such a powerful weapon, providing a means by which a plaintiff can completely invalidate a competitor's patent, it may encourage litigation. ${ }^{190}$ The frequency of the rule's application affects not only the courts, but also litigants, who must pay the cost of litigation.

Furthermore, since the PTO must determine whether the on-sale bar applies before deciding to issue a patent, an inquiry into the commercial history of the invention necessarily makes up a part of each examination. ${ }^{191}$ Given the extremely limited time spent by the PTO in examining each application, this additional burden is quite significant. ${ }^{192}$ Finally, as noted above, the current rule may encourage inventors to file applications for patents that have limited commercial value. ${ }^{193}$ In sum, the current rule may be less costly to administer than its predecessor, but it is not without its own administrative consequences.

\section{G. Summary}

Although the current rule fails to address each of the economic consequences in some cases, is that shortcoming alone enough to justify considering an alternate rule? After all, one struggles to imagine a scenario in which an inventor, by contractually offering her invention for sale, does not raise the possibility of at least one of the negative consequences described above. The current rule to some extent achieves the goal of minimizing the social cost of sales before the filing date. Even so, the case for a new rule is strong. First, the current rule produces a severe outcomethe invalidity of an otherwise deserved patent -in many cases that have a tenuous relationship to the harm that the rule seeks to prevent. The current rule is thus not only a blunt instrument, but also a deadly one. Second, the current rule favors inventors who are able to profit from extensive marketing and from stockpiling their invention through internal manufacturing. In short, the rule favors large corporations. Third, because the current rule is such a powerful weapon, with uncertain effect, the issue is often litigated. ${ }^{194}$ A rule with substantially less value as a litigation weapon, even if

188. Group One, Ltd. v. Hallmark Cards, Inc., 254 F.3d 1041, 1047 (Fed. Cir. 2001).

189. See id. (noting that the previous rule opened "a vast sea of uncertainty" upon its application).

190. A cursory search indicates that the frequency of litigation under the current rule is quite high-over seventy reported cases since Pfaff was decided in 1998.

191. See Manual of Patent Examining Procedure, supra note 149, § 706.02.

192. See Lemley, supra note 184, at 1500 (concluding that patent examiners spend an average of eighteen hours examining each patent).

193. See supra notes $183-84$ and accompanying text.

194. See supra note 190. 
somewhat more costly to administer in any particular case, would therefore result in overall administrative cost savings.

The following section explores several alternate rules, evaluating each against the same set of criteria by which this section evaluated the current rule.

\section{IV}

\section{Proposals for New Standards}

\section{A. The Ideal Solution: A Statutory Sliding Scale Rather Than a Bar}

The on-sale and public use exceptions to patentability in 35 U.S.C. $\S$ 102(b), though located in the section devoted to the "novelty" of the invention, reflect a concern of a different magnitude. ${ }^{195}$ If a patent application describes an invention that is not "novel"-it was previously invented and disclosed to the public by one other than the patent applicant-then the applicant arguably has not provided anything of value to society. ${ }^{196}$ The patent applicant who fails under $\S 102(b)$, however, may have been the very first to disclose to the public an invention of great importance. Yet both applicants lose the right to a patent altogether. The solution proposed here would require four changes to the existing statute, most easily implemented by eliminating $\S 102$ (b) and adding a new section with the following provisions.

First, rather than raising an absolute bar, placing an invention on sale more than one year before the filing date should result in the patent term being shortened by the length of time between the placing on sale and the filing date. Stated differently, if the subject of a patent has been on sale for more than a year before the filing date, then the term of the patent should begin from the date the invention was on sale. ${ }^{197}$

Second, the standard for "on sale" should be de minimis under this rule: any conduct with respect to the invention that is commercial, as opposed to experimental, should trigger the bar.

Third, the PTO should not be required to examine each patent application for violations of the on-sale bar. Most early sales will have no effect on the enforceability of the patent because, in most cases, infringing activity will occur near the beginning of the patent's term. In exceptional cases, defendants may raise the bar in litigation.

195. 35 U.S.C. $§ 102(2000)$ (concerning "[c]onditions for patentability; novelty and loss of right to patent.").

196. See, e.g., 35 U.S.C. $\S 102$ (a) (2000) (denying a patent if "the invention was known or used by others in this country . . . before the invention thereof by the applicant for patent").

197. The same argument applies to the public-use bar and the bar for premature disclosure in a printed publication, also provided by 35 U.S.C. $\$ 102($ b). See infra Part V1. 
Finally, defendants should be able to assert a variant of the recently revived prosecution laches defense in order to bar enforcement of a patent. Under the rule proposed here, an inventor can legitimately prosecute a patent more than one year after the invention was placed on sale. The Federal Circuit has upheld equitable time limits on otherwise permissible patent prosecution-in the related context of so-called submarine patents-in Symbol Technologies, Inc. v. Lemelson Medical ${ }^{198}$ and more recently in In re Bogese. ${ }^{199}$ Under the proposed rule for the on-sale bar, a delay in prosecution once an invention is on sale is permissible; as a result, some equitable limit is critical.

Judge Newman, dissenting in Bogese, stated a formulation of the prosecution laches defense that is appropriate for the on-sale bar. ${ }^{200} \mathrm{~A}$ defendant may assert prosecution laches in a particular lawsuit as an individual defense to infringement, but not as a means for invalidating a patent. ${ }^{201}$ In order to do so, the defendant must prove two elements. One, that the inventor delayed for an "unreasonable and inexcusable length of time" in prosecuting the patent, during which time the inventor "knew or reasonably should have known" that other inventors might rely on the delay in pursuing their own inventive or commercial activity. ${ }^{202}$ Two, that "the delay operated to the prejudice or injury of the defendant." 203

Although facially more complex than the current rule, this proposed solution would be more desirable in practice for the reasons discussed below.

\section{B. An Economic Analysis of the Legislative Solution}

The chief advantage of the proposed solution is that, in most cases, it results in a sanction more proportional to the harm than the current rule would provide.

\section{Monopoly Extension}

Under the proposed solution, any inventor who takes the first steps towards commercialization more than a year before filing a patent application triggers a sanction. The sanction for such a violation is different from that imposed by the current rule. The inventor's finite patent monopoly would be shifted to commence on the date of the first commercial act. This solution directly addresses the concern of maintaining the statutory length

198. 277 F.3d 1361 (Fed. Cir. 2002).

199. 303 F.3d 1362 (Fed. Cir. 2002).

200. Id. at 1371 (Newman, J., dissenting). Judge Newman, unlike the majority, views prosecution laches as a defense against particular infringing acts and not as a means for invalidating a patent. $C f$. id. at 1368 .

201. Id. at 1371 (Newman, J., dissenting).

202. Id. (Newman, J., dissenting) (stating the analogous rule for conventional laches).

203. Id. (Newman, J., dissenting). 
of the monopoly by ensuring that an inventor does not unfairly profit from an invention more than one year before filing for a patent.

Applying the proposed rule to the hypothetical involving Sam and Sumo, Inc., both inventors would receive a patent on their inventions, but with shortened terms. ${ }^{204}$ Sumo's patent would begin at the date it first began to market its peripheral, which is before Sam offered to sell his peripheral to his neighbor.

This result is preferable to that obtained under the current rule for several reasons. First, Sam does not lose his right to a patent by virtue of a transaction that yielded no financial benefit. Conversely, Sam need not rush to obtain a potentially useless patent on an invention that may have no commercial value. Second, Sumo receives a patent term expiring sooner than Sam's, which is proper given that Sumo's conduct presumably allowed it to profit from its invention sooner than Sam profited from his. Third, though under the proposed rule Sumo is free to market its invention without fear of losing a patent altogether, Sumo will only do so if marketing will yield a greater profit than actually offering the invention for sale to the public. ${ }^{205}$

\section{Consumer Reliance}

As discussed above, consumers suffer harm from relying on the unpatented status of an invention only when the inventor charges a lower price before the patent attaches, and a higher price afterwards. Under the proposed standard, an inventor is unlikely to do so since the patent term begins at least as early as the first sale, subject to the one-year grace period. Thus, an inventor who chooses to sell the invention at a low price is squandering some of the monopoly's value. Even under today's rule, a patentee is certainly free to charge a low price at the beginning of a patent term, raising it only after the public has developed an interest in the invention. ${ }^{206}$

204. See supra Introduction.

205. In other words, Sumo internalizes the full social cost of marketing the invention rather than being able to market the invention indefinitely with no penalty, as under the current rule.

206. Under current law, an inventor is also free to withhold information about a pending patent application even when the patented technology is under consideration by a standard-setting body. Rambus, lnc. v. Infineon Techs. AG, 318 F.3d 1081, 1105 (Fed. Cir. 2003). Rambus was decided by a divided panel of the Federal Circuit; it is conceivable that more aggressive attempts by inventors to inducc public relianee - by establishing their inventions as de jure or de facto standards-would be grounds for rendering a patent invalid or unenforceable, either under the current or proposed rule. For discussions of the complex economics underlying patented inventions that are embedded in standards, see Mark A. Lemley, Intellectual Property Rights and Standard-Setting Organizations, 90 CaLIF. L. REv. 1889 (2002); and Patterson, supra note 141. Finally, it is likely that any aggressive attempt by an inventor to induce public reliance will induce reliance by other inventors. Under the proposed rule, other inventors will be able to defend against fraudulent conduct through the prosecution laches defense. Parties successfully asserting this defense will be able to continue their otherwise infringing activity, thus reducing the patentee's ability to charge monopoly prices. 
The proposed rule ensures that any such price manipulation will occur within the allowed twenty-year period.

\section{Inventor Reliance}

The sliding patent term alone does not guard adequately against reliance by other inventors. An inventor may rationally delay in filing in order to ensure market interest, and in so doing inadvertently harm other inventors who have invested in improving or replicating the subsequently patented invention. An inventor also might deliberately delay, hoping to establish a community of potential licensees before the patent issues.

The proposed prosecution laches defense targets this reliance directly. The defense is equitable; courts may adjust it for particular instances of egregious conduct or severe harm. Certain factors make the defense more likely to succeed. First, a long delay by the patentee is more likely to be unreasonable. Second, commercial success of the patented invention increases the likelihood that the patentee should have known that other inventors would seek to duplicate or improve upon the patented invention. Third, an inventor who invested substantial time and effort in duplicating or improving the patented invention will be better able to show prejudice. An inventor that simply made use of the patented invention with little independent effort will have a correspondingly more difficult time establishing actual prejudice. In sum, the prosecution laches defense, unlike any element of the current contractual standard, provides a remedy precisely targeted at the kind of inventor reliance that the on-sale bar should seek to prevent.

\section{Delayed Filing and Disclosure}

The analysis of reliance by other inventors applies equally to this category of harm. The prosecution laches defense will provide a strong incentive to file quickly.

Unlike the current rule, the proposed solution allows an inventor to disclose an invention independently of filing for a patent, without jeopardizing the right to a patent altogether. If the effect of placing an invention on sale is to disclose the invention to the public, under the proposed rule the inventor may do so and still obtain a patent, though one whose term begins at the time of the sale. Even under the proposed rule the inventor has some incentive to put off the first sale and disclosure of the invention to the public in order to not lose the one-year grace period permitted before filing. Still, under the proposed rule, if placing the invention on sale is the best way to determine its value, an inventor may do so with only five percent of the patent term at stake. 


\section{Redundant Inventive Effort}

The arguments that the new rule will encourage prompt disclosure apply equally to this source of harm. Public disclosure marks the end, at least in theory, of duplicate inventive effort.

\section{Administrative Costs}

The proposed rule will have an immediate effect on the cost of prosecution borne by the PTO by no longer requiring a search for on-sale bar violations during the course of patent prosecution. As noted above, the proposed rule will also likely decrease the number of applications filed, by allowing inventors to use the market to identify which patents would be valuable enough to prosecute. ${ }^{207}$

The proposed change will also decrease the court's burden of administering the on-sale bar by decreasing the frequency of $\S 102$ (b) claims. Because a violation of the on-sale bar currently invalidates a patent altogether, a defendant in a patent suit possesses a powerful litigation weapon. The on-sale issue also may encourage litigation because of the incentive structure of the current system, which encourages inventors to file as close to exactly one year after the first sale as possible. ${ }^{208}$ When patentees engage in substantial marketing activity prior to the critical date, a defendant will be tempted to engage in extensive and costly discovery in order to look for any single instance of a binding, contractual offer.

Under the proposed standard, whether there was a sale before the critical date will most often not affect the outcome of the suit. In most cases the infringing activity will have occurred within twenty years of the first sale, making a determination of the beginning of the statutory term irrelevant. The only salient disputes about timing will focus on the end of the patent grant in order, for instance, to draft an appropriate license agreement.

Disputes about the proper end date of a patent grant will almost certainly occur less often than disputes about a patent's validity because an accused infringer has so much more to gain by proving invalidity absolutely. In many cases the value of a patent decreases over time as other technologies arise that provide substitutes for the patented invention. ${ }^{209}$ Litigating about the exact end date of a patent covering an obsolete technology is pointless.

The complexity of litigating an on-sale bar claim will be higher under the proposed rule than under the current one. "Marketing activity," unlike a

207. For a discussion of why a company will often file a patent application prior to the point at which the company is certain of the application's value, see supra note 183 and accompanying text.

208. See supra Part III.D.

209. See generally Dan L. Burk \& Mark A. Lemley, Policy Levers in Patent Law, 89 VA. L. Rev. 1575 (2003). 
contractual offer, lacks an established legal definition. Also, since any litigation under the proposed rule will likely occur roughly twenty years after the alleged commercial activity took place, the accused infringer will have more difficulty obtaining evidence. Though this increase in complexity offsets some of the benefit of reducing the frequency of litigation, the substantial reduction in the number of claims may have a larger effect.

One objection to the proposed sliding-scale rule for the on-sale bar is that the same balancing argument could apply to other considerations such as nonobviousness and utility. Inventions that are somewhat nonobvious or somewhat useful arguably deserve some length of patent protection less than the full twenty-year term. Were the argument underlying the current proposal extended to its logical limit, the entire patent system would collapse under the administrative burden of determining the exact temporal scope of each patent grant.

However, the on-sale bar, unlike the requirements of nonobviousness and utility, is expressly concerned with timing. The legislative change proposed here simply moves the beginning of the patent term in some cases to another objectively measurable point. ${ }^{210}$ Implementing a time-flexible utility or nonobviousness requirement, in contrast, would require translating a difference in the value of the patent to a difference in the length of protection that should be granted. Given the present lack of empirical data on what the optimal length of patent term is for any invention, and the expected variation among different fields, this task is practically impossible. $^{211}$

The proposed rule will also lead to lower circumvention costs. Circumvention would be more difficult because the marketing standard provides a sensitive trigger for sanctions. Moreover, the proposed sanctions reduce waste because the patent still retains most of its value even if the inventor receives a shortened patent term.

Finally, by reducing the frequency of litigation and the number of patents invalidated, the proposed rule reduces the cost of errors by both the PTO and the inventor. A patent examiner issuing a patent on an invention already on sale to the public will be confident that, at the worst, the term will end slightly earlier than expected.

\section{Summary}

The sliding-scale standard improves the current rule primarily by preventing commercial exploitation outside the patent term and by reducing administrative costs associated with the on-sale bar. Where the slidingscale standard is weakest, in preventing harmful reliance by other inventors, the extension of the prosecution laches defense provides a remedy.

210. For a discussion of this problem in the context of statutes of limitations, see infra Part V.

211. See supra note 135 and accompanying text. 


\section{Alternative Legislative Proposals}

Short of the complete change proposed in this Comment, Congress could amend $\S 102(b)$ to require a showing of substantial public harm as a prerequisite for invalidating a patent or avoid the need for the on-sale bar altogether by changing from a first-to-invent to a first-to-file system.

The first alternate proposal would only raise the bar if the accused infringer could show substantial public harm arising from the patentee's failure to file the application. Examples of this harm might include: (1) price changing behavior, which might give rise to a presumption of public harm; (2) inventive activity by other parties that continued during the period of the patentee's inaction; and (3) evidence that the patentee was able to keep the invention secret for a long period of time, thus depriving other inventors from its benefit while subjecting the public to monopoly prices.

The second possibility is that Congress will change the patent system from a first-to-invent standard to a first-to-file standard. Based on the economic analysis of the filing incentives present in the current system, this change would largely eliminate the need for an on-sale bar. ${ }^{212}$ If an inventor, by placing her invention on sale before the filing date, discloses the invention to the public, then she runs the risk that another party will beat her to the patent office. An inventor may try to protect the invention as a trade secret, but the risk still exists that another inventor will independently discover the same invention. Under a first-to-file regime, this second inventor can obtain the patent that the first inventor did not by being the first to file. Given the choice between starting the patent term clock running through a prompt filing and risking losing the entire patent, most inventors will file quickly.

\section{Compromise Solutions: Changes to Judicial Doctrine}

Barring any legislative change, courts may only modify the on-sale bar within the confines of the current statutory language in $\S \mathrm{I02(b).} \mathrm{Thus,}$ any test must find support in the language of the statute, which states that "[a] person shall be entitled to a patent unless ... the invention was ... on sale in this country, more than one year prior to the date of the application for patent." 213

Historically, the phrase "on sale" has provided the most room for interpretation. As discussed earlier, in the past courts have determined whether a patentee's conduct violated the policies underlying the bar on a case-by-case basis. ${ }^{214}$ Although the Supreme Court in Pfaff criticized the vague weighing of facts and policies inherent in this test, the Federal

212. See supra Part II.C-D.

213. 35 U.S.C. $\$ 102(b)(2000)$.

214. E.g., UMC Elecs. Co. v. United States, 816 F.2d 647 (Fed. Cir. 1987). 
Circuit might be able meet $P$ faff s requirement of definiteness with a more carefully articulated policy-based test. ${ }^{215}$

As discussed above, application of the current rule results in a bar to patentability even when the sale has not upset the statutory balance. A contractual offer is a poor proxy for most of the societal harms flowing from an early sale. For most of the harms discussed above, the current rule errs both in failing to raise the bar when harm has occurred, and in raising the bar even when no harm has occurred. In guarding against unfair reliance by consumers, though, the current rule errs primarily in raising the bar too often, even when no such reliance has taken place.

This systematic failure suggests how the current judicial test might be improved. Rather than raising the bar for any contractual offer, courts should only do so when the offer was made to the public, creating the possibility of public reliance.

The language of Pfaff itself provides an opportunity for this more narrow interpretation. The first prong of the Pfaff test requires a "commercial offer for sale," and the reasoning of the Court turned on the inventor's ability to control the timing of the first "commercial marketing" of the invention. $^{216}$ The court in Group One already made much of the word "commercial" in its finding that the offer must be contractual. ${ }^{217}$ The word "marketing," however, suggests a further limitation on the offer, in that it is defined in part as "all business activity involved in the moving of goods from the producer to the consumer."218 The word "market" is defined as " $[t]$ he meeting or congregating together of people for the purchase and sale of provisions or livestock, publicly exposed." 219 Both definitions suggest that marketing generally refers to activities directed at the consuming public.

The Federal Circuit could define "public" very broadly and still improve the current rule. A broad definition would ignore the different meanings of "consumer" in different industries; any consumer of a patented product may suffer as a result of relying on the product's availability. At a minimum, the Federal Circuit should exclude the inventor from its definition of "consumer."

Adjusting the rule in this way would change the result reached in Special Devices, but the adjustment would not affect cases such as Micrel that involve excessive marketing activity. Short of a legislative solution, however, the courts are constrained both by the statutory language of $\S$ 102(b) and the requirement of definiteness outlined in Pfaff. With such

215. Pfaff v. Wells Elecs., 1nc., 525 U.S. 55, 65 n.11 (1998).

216. Id. at 67.

217. 254 F.3d 1041, 1046 (Fed. Cir. 2001).

218. Webster's New World Dictionary 868 (David B. Guralnik ed., 2d Coll. ed. 1982).

219. Oxford English Dictionary 384 (J.A. Simpson \& E.S.C. Weiner eds., $2 d$ ed. 1989). 
limited room to maneuver, creating a comprehensive judicial fix for the current policy mismatch is unlikely.

\section{V}

\section{EPILOGUE: OTHER All-OR-NOTHING RULES}

The shortcomings of the current on-sale bar are not unique to $\S$ 102(b), or even to patent law. The courts have failed to articulate a workable standard for what conduct serves to trigger the bar because, as noted above, using any single act as a proxy for social harms that occur over time requires either intractable vagueness and complexity (as in the totality of the circumstances test) or significant inaccuracy (as in the current contractual test). The problem with the current test is structural-a mismatch between a discrete judicial determination and a complex set of possible circumstances. This section briefly notes a few other rules, in patent law and beyond, that exhibit similar structural defects. ${ }^{220}$

The other statutory bars of $\S 102(b)$ are perhaps the most obvious example of other rules with similar structural problems. Section 102(b) contains, in addition to the on-sale bar, the related public-use and printedpublication bars. ${ }^{221}$ Public use or disclosure of an invention, like public marketing, raises the possibility of reliance-on the part of consumers and other inventors. Public use or disclosure does not raise precisely the same concerns with monopoly extension as marketing activity or an offer to sell, but to the extent that use and disclosure are marketing tactics, they may also lead to increased consumer interest. The current rule for public use is, oddly, a variant of the totality of the circumstances test abrogated by the Supreme Court in Pfaff..$^{22}$ This standard may have persisted in the publicuse context because there is no body of law related to "use" that is analogous to contract law with respect to "sales." As discussed above, any standard that attempts to determine whether a single instance of use upsets the statutory balance is necessarily complex and unpredictable. A public use, like the beginning of commercial activity, could serve as the triggering event for the beginning of the patent term under a variant of the rule that this Comment proposes.

220. The enumeration that follows is not exhaustive; nor is the analysis of any of the rules meant to be complete. The purpose, rather, is to point out that other scholarship that has uncovered the same analytical flaw and to suggest other rules that might benefit from similar scrutiny.

221. 35 U.S.C. $\S 102(b)$ (2000) (denying patentability where "the invention was patented or described in a printed publication in this or a foreign country or in public use or on sale in this country, more than one year prior to the date of the application for patent in the United States" (emphasis added)).

222. Netscape Communications Corp. v. Konrad, 295 F.3d 1315, 1320 (Fed. Cir. 2002) ("We look to the totality of the circumstances when evaluating whether there has been a public use within the meaning of section 102(b)."); $c f$. Pfaff v. Wells Elecs., Inc., 525 U.S. 55, 66 n.11 (1998) (disapproving of the totality of the circumstances test for the on-sale bar). 
Another set of all-or-nothing rules, frequently encountered in litigation, are statutes of limitations. In $A$ New Approach to Old Cases: Reconsidering Statutes of Limitations, Professor Ehud Guttel and Michael Novick note that all-or-nothing statutes of limitations are not responsive to concerns related to the decay of evidence. ${ }^{223}$ Statutes of limitations, they argue, should serve to minimize the harm resulting from the erosion of evidence and to distribute any such harm appropriately between plaintiff and defendant. ${ }^{224}$ All-or-nothing statutes of limitations fail to achieve these goals because plaintiffs may file suit before the statutory period ends, even if evidence has been eroded, and may not file suit afterwards, even if no evidence has been lost. ${ }^{225}$ The paper proposes that plaintiffs who delay in filing suit should pay for the actual harm caused by loss of evidence through a reduced recovery. ${ }^{226}$ This proposal is analogous to requiring an inventor to internalize the cost of a pre-filing sale; in both cases the party subject to the penalty faces an incremental cost rather than an absolute prohibition. ${ }^{227}$

Finally, the California courts have recently struggled to define the level of conduct required to trigger punishment under a statute proscribing the "willful" failure of a sex offender to renew his or her registration under California's sex offender registration statute. ${ }^{228}$ The registration requirements allow police to know the whereabouts of convicted sex offenders, in order to monitor them and discourage recidivism. ${ }^{229} \mathrm{~A}$ sex offender must register within five working days of his birthday each year. Any offender who "willfully" fails to register within the prescribed period may face incarceration, even if he later contacts the police and registers. ${ }^{230}$ Courts have grappled with whether a willful failure requires actual knowledge of the registration requirement, ${ }^{231}$ and whether a sex offender who honestly forgets to register, but has no intention of evading the authorities,

223. Ehud Guttel \& Michael T. Novick, A New Approach to Old Cases: Reconsidering Statutes of Limitation, 54 U. TORONTO L.J. 129, 130 (2004).

224. Id. at 133 .

225. Id. at 131-32.

226. Id. at 132-33.

227. As Guttel and Novick note, replacing all-or-nothing rules with an incremental "price" is part of a larger trend from sanctions to prices in other areas of law. Id.; see generally Robert Cooter, Prices and Sanctions, 84 CoLum. L. Rev. 1523 (1984). One differencc between Guttel and Novick's proposal and the proposal in this Comment is the nature of the price. Reducing a plaintiff's recovery based on evidentiary loss requires a court to calculate the "error cost" associated with the lost evidence, a monetary value. Guttel \& Novick, supra note 223, at 133-34. Reducing the value of the inventor's patent, however, requires only a reduction in the length of time of the patent term. The proposal in this paper thus requires no translation of time to money.

228. E.g., People v. Barker, 131 Cal. Rptr. 2d 801, review granted, 70 P.3d 981 (Cal. 2003);

People v. Cox, 94 Cal. App. 4th 1371 (2002).

229. Cox, 94 Cal. App. 4th at 1376-77.

230. People v. Garcia, 23 P.3d 590, 593 (Cal. 2001).

231. Garcia, 23 P.3d at 594. 
is guilty of willful failure to register. ${ }^{232}$ As with other all-or-nothing rules discussed in this section, the problem with the registration statute is that the offender's failure to adhere to a deadline is not necessarily a good indication of whether the offender desires to evade police surveillance. Some offenders with no desire to escape surveillance will fail to register, and others will register but escape surveillance in other ways.

The examples in this section are not exhaustive. Any all-or-nothing, time-based rule may suffer from similar structural problems. As this Comment illustrates, where courts struggle to formulate an acceptable standard for such all-or-nothing rules, the solution may lie not in a better standard, but in a rule whose structure more closely conforms to the balance that it seeks to maintain.

\section{CONCLUSION}

The current on-sale bar is unduly harsh and does not fulfill the economic goals of patent law. The solutions proposed here address both the harshness, by limiting the sanction or restricting its application to only severe breaches of the statutory balance, and the economic goals, by focusing the inquiry more directly on the types of actions that cause harm. The proposal presented in this Comment employs finely tuned triggers for sanctions and a sliding-scale sanction that adjusts to match the harm each case presents. These measures not only prevent monopoly extension through activity that escapes the narrow definition of sales, but also reduce administrative costs by decreasing on-sale bar claims and the number of invalidated patents. Even if Congress does not amend the statute, courts should feel encouraged to take an active role in making the rule more equitable by focusing on the underlying economic rationales. 
